\title{
Arginine, citrulline, and nitric oxide metabolism in end-stage renal disease patients
}

\author{
Titus Lau, ${ }^{1}$ William Owen, ${ }^{1}$ Yong Ming Yu, ${ }^{2}$ Natan Noviski, ${ }^{3}$ Jeremy Lyons,, 4 \\ David Zurakowski, ${ }^{6}$ Rita Tsay, ${ }^{5}$ Alfred Ajami, ${ }^{7}$ Vernon R. Young, ${ }^{5}$ and Leticia Castillo, ${ }^{4,5}$
}

${ }^{1}$ Renal Division, Department of Medicine, Brigham and Women's Hospital,
Boston, Massachusetts, USA
${ }^{2}$ Shriners Burn Hospital, and
${ }^{3}$ Pediatric Department, Massachusetts General Hospital, Boston, Massachusetts, USA
${ }^{4}$ Department of Anesthesia, Children's Hospital, Boston, Massachusetts, USA
${ }^{5}$ Laboratory of Human Nutrition and Clinical Research Center, Massachusetts Institute of Technology,
Cambridge, Massachusetts, USA
${ }^{6}$ Department of Research Computing, Children's Hospital, Boston, Massachusetts, USA
${ }^{7}$ MassTrace Inc., Woburn, Massachusetts, USA

Address correspondence to: L. Castillo, Department of Anesthesia, Children's Hospital,

Farley 517, 300 Longwood Avenue, Boston, Massachusetts 02115, USA.

Phone: (617) 355-7327; Fax: (617) 734-3863; E-mail: Leticia.Castillo@TCH.Harvard.Edu.

Received for publication April 27, 1999, and accepted in revised form March 7, 2000.

\begin{abstract}
The kidneys are thought to be a major site of net de novo arginine synthesis, but the quantitative status of arginine metabolism and its substrate precursor relationship to nitric oxide (NO) synthesis in end stage renal disease (ESRD) patients have not been characterized. We have investigated kinetic aspects of whole body arginine metabolism in six patients with ESRD. They received two pre- and two post-hemodialysis intravenous tracer infusion studies with L-[guanidino- ${ }^{15} \mathrm{~N}_{2}$ ]arginine and L$\left[{ }^{13} \mathrm{C}\right]$ leucine during the first study, and $\mathrm{L}-\left[5-{ }^{13} \mathrm{C}\right]$ arginine and $\mathrm{L}-\left[5-{ }^{13} \mathrm{C}\right.$-ureido, $\left.5,5,{ }^{2} \mathrm{H}_{2}\right]$ citrulline during the second study. Arginine homeostasis in ESRD patients was found to be associated with a lower rate of arginine oxidation, and despite the decrease in renal function, the rate of de novo arginine synthesis appeared to be preserved. Plasma citrulline concentrations and flux were also elevated in these subjects compared with healthy adults. The rate of whole body NO synthesis was increased in the ESRD patients, but apparently not different pre- and post-hemodialysis therapy. The anatomic site(s) responsible for the maintenance of net de novo arginine synthesis and for the elevated NO synthesis and its pathophysiological importance in ESRD remain to be established.
\end{abstract}

J. Clin. Invest. 105:1217-1225 (2000).

\section{Introduction}

Arginine, traditionally considered to be a nutritionally dispensable (nonessential) amino acid, serves multiple functions in addition to its role in protein synthesis (1). It is the precursor of nitric oxide (NO) (2), creatine, agmatine, and other polyamines $(3,4)$, and is an intermediate in the urea cycle. The kidneys are thought to be the main site of net de novo arginine synthesis, which would contribute to the maintenance of wholebody arginine homeostasis (5-10).

Despite the potential pathophysiologic significance of altered arginine metabolism in end-stage renal disease (ESRD) (11-13), in which reduced arginine synthesis is hypothesized, there are no in vivo studies of the quantitative aspects of arginine and arginine-NO kinetics for this group of patients. However, such information is necessary for the development of safe and effective therapeutic strategies aimed at modulating arginine metabolism and its several functions.

Therefore, in this study we have examined plasma kinetics of arginine and assessed the activity of the L-arginine-NO pathway in adults with ESRD. The possible effects of hemodialysis on arginine and NO kinetics were also explored. Because maintenance hemodialysis has been thought to be responsible for protein (nitrogen) catabolic stress $(14,15)$, we also investigated leucine kinetics as an indicator of the dynamic status of wholebody protein metabolism (16). Our findings reveal that at the whole-body level, net de novo arginine synthesis is maintained in ESRD patients, possibly due to an adaptive increase in citrulline availability and turnover. In addition, NO production in ESRD patients was significantly increased, when compared with healthy adults, but was apparently not influenced acutely by hemodialysis.

\section{Methods}

Study subjects and dialysis treatment. Eight African-American patients, 4 women and 4 men, with ESRD treated by maintenance hemodialysis, were studied. All patients were clinically stable and without intercurrent acute illness. Their clinical characteristics are shown in Table 1. Dialysis was performed 3 times a week during 3 -hour sessions, using polysulfone dialyzers. Their urea clearance rate was maintained at $\geq 65 \%$. 


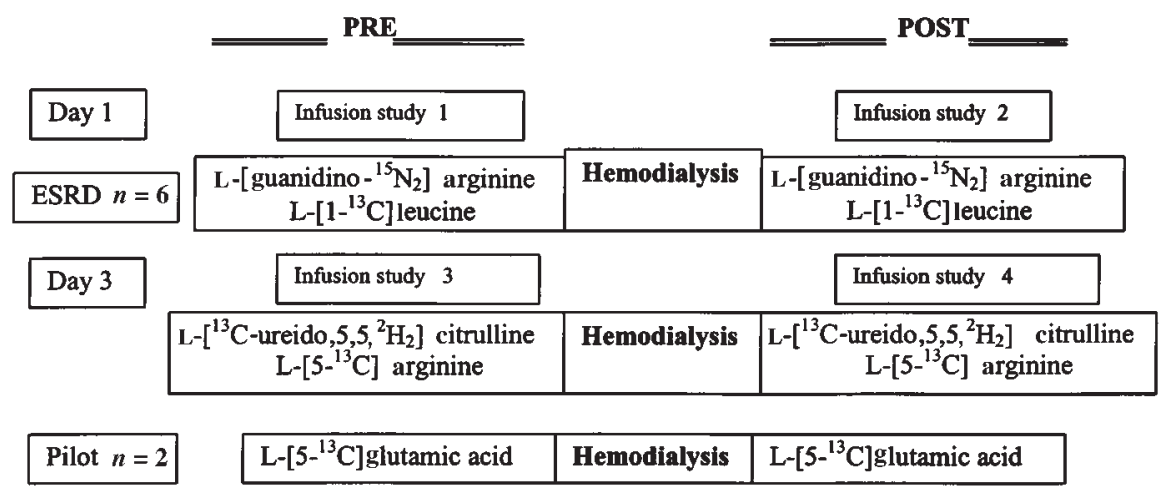

Figure 1

Schematic outline of the time and order of the 4 tracer study protocols for ESRD patients. In addition, a pilot study with 2 patients was undertaken to determine the recovery of ${ }^{13} \mathrm{CO}_{2}$ in expired air after $\mathrm{L}-\left[5-{ }^{13} \mathrm{C}\right]$ glutamic acid infusion.

For further evaluation of the results in this experiment, we refer to studies carried out previously in our laboratories in a control population of healthy subjects, using a similar tracer protocol $(17,18$; and L. Castillo et al., unpublished data). These controls included 12 healthy adults (age $21 \pm 3$ years; weight $77.6 \pm 19 \mathrm{~kg}) ; 6$ subjects were studied for determination of arginine homeostasis (17), and the other 6 were used in a study aimed to determine the rates of NO synthesis (18). There were some differences in experimental design between this study and our earlier studies in healthy subjects, as discussed below.

Materials. L-[guanidino- ${ }^{15} \mathrm{~N}_{2}$ ] arginine (99 atom \%), L$\left[5-{ }^{13} \mathrm{C}\right]$ arginine (99 atom \%), L- $\left[5-{ }^{13} \mathrm{C}\right.$-ureido, $\left.5,5,{ }^{2} \mathrm{H}_{2}\right]$ citrulline (99 atom \%), L- $\left[5-{ }^{13} \mathrm{C}\right]$ glutamic acid (99 atom \%), and $\mathrm{L}-\left[1-{ }^{13} \mathrm{C}\right]$ leucine (99 atom \%) were purchased from MassTrace Inc. (Woburn, Massachusetts, USA). $\mathrm{NaH}^{13} \mathrm{CO}_{3}$ (95 atom \%) was purchased from Cambridge Isotopes (Andover, Massachusetts, USA).

Study protocol. The study protocol was approved by the Human Studies Committee and was conducted at the Clinical Research Center (CRC), Brigham and Women's Hospital, Boston, Massachusetts, USA. After a description of the studies and the possible risks, the patients gave their written consent to proceed. No dietary modifications were undertaken in this study, with patients given their usual diets, intended to supply adequate intake of protein and energy. The overall experimental design is shown in Figure 1, and an outline of the tracer infusion studies are depicted in Figure 2. Six patients received 4 tracer infusion studies of 8 hours each. Two other patients received 2 infusion studies for determination of $\mathrm{H}^{13} \mathrm{CO}_{3}$ recovery from an infusion of $\mathrm{L}-\left[5-{ }^{13} \mathrm{C}\right]$ glutamic acid. On the day of the tracer infusion study, dietary intake was recorded. Patients were given their evening meal at 1700 hours (Figure 2a), and the tracer infusion study began at 2200 hours. Blood drawings for plasma isotopic enrichment during the postabsorptive steady state were obtained every 20 minutes from 0100 hours to 0200 hours. The tracer infusion study continued, and at 0400 hours the patients received a breakfast designed to provide about $1 / 3$ of their daily dietary intake. Actual intakes were recorded and estimates of arginine and leucine intakes were made for that feeding period, during which blood and expired air samples were collected as follows. For purposes of estimating fed-state arginine and leucine kinetics, we assumed that the equivalent of $1 / 3$ of the meal was absorbed during each hour. The tracer infusion study was stopped at 0600 hours, and the patients then received their conventional hemodialysis treatment. Once hemodialysis was completed, the patients returned to the CRC, and at 1200 hours a post-hemodialysis infusion study was begun (Figure $2 \mathrm{~b}$ ) that lasted for 8 hours. Patients received lunch at the beginning of this tracer study, but did

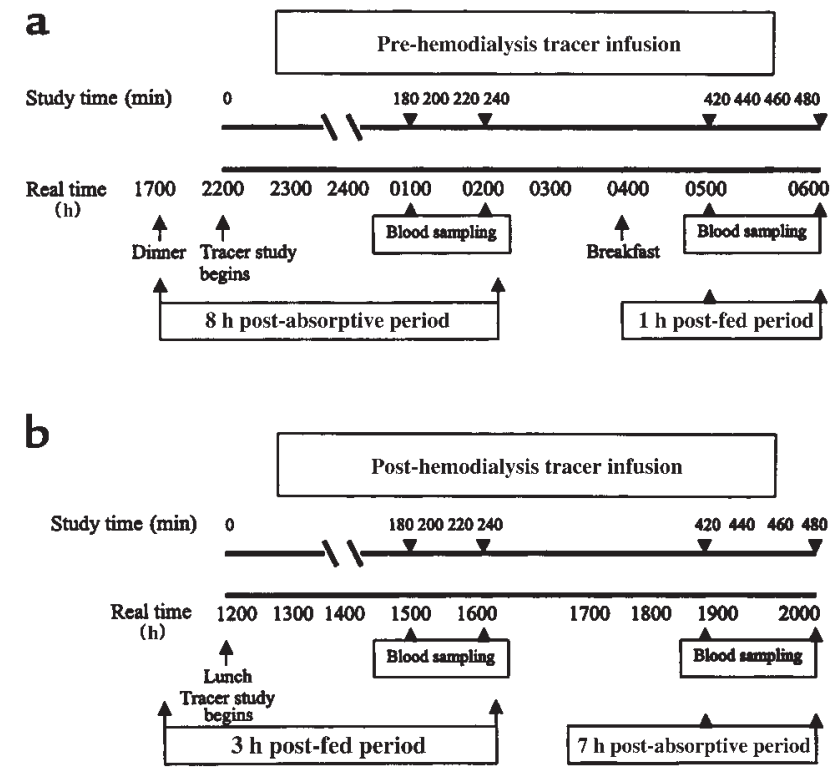

Figure 2

Schematic representation of the pre- (a) and post-hemodialysis (b) tracer infusion studies including times of sampling and meals. 
Table 1

Clinical characteristics of patients with ESRD studied for arginine metabolism

\begin{tabular}{|c|c|c|c|c|c|c|}
\hline $\begin{array}{l}\text { Patient } \\
\text { Number }\end{array}$ & initial diagnosis & $\begin{array}{l}\text { Age/sex } \\
\text { (years) }\end{array}$ & $\begin{array}{l}\text { Weight }^{\mathrm{A}} \\
(\mathrm{kg})\end{array}$ & Venous pH & $\mathrm{TCO}_{2}{ }^{\mathrm{B}}$ & $\begin{array}{l}\text { Serum } \\
\text { albumin }\end{array}$ \\
\hline 1 & Hypertension & $64 / M$ & 62 & 7.42 & 33 & 3.7 \\
\hline 2 & Hypertension & $46 / \mathrm{M}$ & 76 & 7.4 & 26 & 3.5 \\
\hline 3 & Focal glomerulosclerosis & $31 / \mathrm{M}$ & 58 & 7.42 & 36 & 4.1 \\
\hline 4 & Cryptogenic & $62 / \mathrm{F}$ & 76 & 7.41 & 30 & 4.0 \\
\hline 5 & Hypertension & $68 / \mathrm{F}$ & 46 & 7.37 & 37 & 4.1 \\
\hline 6 & Hypertension & $68 / F$ & 79 & 7.39 & 34 & 4.6 \\
\hline 7 & Hypertension & $73 / \mathrm{M}$ & 75 & 7.39 & 31 & 3.7 \\
\hline 8 & Hypertension & $68 / F$ & 72 & 7.40 & 26 & 4.1 \\
\hline Mean \pm SD & & $53.5 \pm 14$ & $68 \pm 10$ & $7.40 \pm 0.01$ & $31.6 \pm 3.9$ & $3.9 \pm 0.3$ \\
\hline
\end{tabular}

not consume additional food until the tracer study was terminated. Blood drawings for isotopic enrichment during this fed/post-hemodialysis state were obtained every 20 minutes from 1500 hours to 1600 hours. Again we assumed, for purposes of approximating leucine and arginine absorption during this sampling period, that absorption was equivalent to $1 / 4$ of the total amount consumed at lunch. The tracer infusion study was continued until 2000 hours. From 1900 hours to 2000 hours blood samples were collected to measure isotopic enrichment during the post-absorptive/post-hemodialysis period, for comparison with the equivalent predialysis phase (i.e., 0100-0200 hours).

Details of the procedures followed during the infusion studies have been described (18-22). Briefly, a 20gauge antecubital angiocatheter was used for tracer infusion, and blood was collected through a second angiocatheter placed in a retrograde fashion in a dorsal hand vein. The hand was placed in a custom-made warming box at $68^{\circ} \mathrm{C}$ for $\geq 20$ minutes before collection of samples. Isotope tracers were infused by means of a calibrated syringe pump (Harvard Apparatus Co., South Natick, Massachusetts, USA).

For the 6 patients in the main study, the following combinations of isotopes were given: During the first tracer day (Day 1 in Figure 1) the patients received (both pre- and post-hemodialysis) a primed, constant, intravenous infusion of $\mathrm{L}$-[guanidino- ${ }^{15} \mathrm{~N}_{2}$ ] $\operatorname{arginine}$ and $\mathrm{L}-\left[1-{ }^{13} \mathrm{C}\right]$ leucine, at known rates of $5 \mu \mathrm{mol} / \mathrm{kg}$ (prime infusion) and $5 \mu \mathrm{mol} / \mathrm{kg}$ per hour (constant infusion), and $4 \mu \mathrm{mol} / \mathrm{kg}$ (prime infusion) and 4 $\mu \mathrm{mol} / \mathrm{kg}$ per hour (constant infusion). During the second phase (day 3 in Figure 1), carried out 48 hours later, the patients received (pre- and post-hemodialysis) primed, constant, intravenous infusions of $\mathrm{L}-\left[{ }^{13} \mathrm{C}\right.$ ureido, $\left.5,5,{ }^{2} \mathrm{H}_{2}\right]$ citrulline and $\mathrm{L}-\left[5-{ }^{13} \mathrm{C}\right]$ arginine at known rates of about $1 \mu \mathrm{mol} / \mathrm{kg}$ and $1 \mu \mathrm{mol} / \mathrm{kg}$ per hour; and $5 \mu \mathrm{mol} / \mathrm{kg}$ and $5 \mu \mathrm{mol} / \mathrm{kg}$ per hour, respectively (prime and constant infusions). With these combinations of tracers we aimed to determine (a) plasma fluxes of arginine, citrulline, and leucine, and oxidation rates of arginine and leucine; (b) net rate of de novo arginine synthesis, by measurement of con- version of $\left[{ }^{13} \mathrm{C}\right.$-ureido, $\left.5,5,{ }^{2} \mathrm{H}_{2}\right]$ citrulline to $\left[{ }^{13} \mathrm{C}\right.$-guanidino, $\left.5,5,{ }^{2} \mathrm{H}_{2}\right]$ arginine (19); (c) rates of $\mathrm{NO}$ production, as determined by the stoichiometric reaction involving conversion of $\left[{ }^{15} \mathrm{~N}_{2}\right]$ arginine to $\left[{ }^{15} \mathrm{~N}\right]$ citrulline (18). The relationships between the tracers used on day 1 and day 3 and their metabolic derivatives are depicted in Figure 3, a and b, respectively.

The rate of arginine oxidation was determined from the appearance of ${ }^{13} \mathrm{C}$ in expired air. However, not all of the ${ }^{13} \mathrm{C}$ that leaves the arginine pool due to oxidation of arginine to form ornithine and then glutamic acid appears in the expired air. To correct for total ${ }^{13} \mathrm{C}$ retention, 2 patients received, pre- and post-hemodialysis, a primed, constant intravenous infusion of $\mathrm{L}-\left[5-{ }^{13} \mathrm{C}\right] \mathrm{glu}-$ tamate $(1 \mu \mathrm{mol} / \mathrm{kg}$ prime infusion and $1 \mu \mathrm{mol} / \mathrm{kg}$ per hour continuous infusion).

Blood and breath collection and analyses. Blood and breath samples were obtained at time 0 and at 180, 200, 220, 240 , and then at $420,440,460$, and 480 minutes during each tracer study, for determination of plasma amino acid concentrations, isotopic enrichment of the amino acid tracers, and ${ }^{13} \mathrm{CO}_{2}$ enrichment in expired breath during the post-absorptive and fed periods (Figure 2) respectively, all as described previously $(16,19,22)$.

Indirect calorimetry. Carbon dioxide production $\left(V \mathrm{CO}_{2}\right)$ and oxygen consumption $\left(V_{2}\right)$ rates were determined with the aid of an indirect calorimeter (DeltaTrac; SensorMedics Corp., Anaheim, California, USA), as described previously (16). Six measurements (3 during the post-absorptive state and 3 during the fed states, pre-and post-hemodialysis), were obtained over the 8-hour tracer infusion period. The system was calibrated using a standard gas sample provided by the manufacturer $\left(96 \% \mathrm{O}_{2}\right.$ and $\left.4 \% \mathrm{CO}_{2}\right)$.

Diet. No dietary manipulations were conducted in this study, and before the tracer studies no restrictions were required of the patients. They were offered adequate protein and energy intakes in the form of mixed meals; not all food given was consumed, but records of leavings were taken. Estimates of the total intake of arginine and leucine during the tracer studies are given in Results. The daily intake (mean \pm SD) of protein was $1.1 \pm 0.4 \mathrm{~g} / \mathrm{kg}$ per day pre-hemodialysis and $1.5 \pm 0.5 \mathrm{~g} / \mathrm{kg}$ per day post-hemodialysis. The 

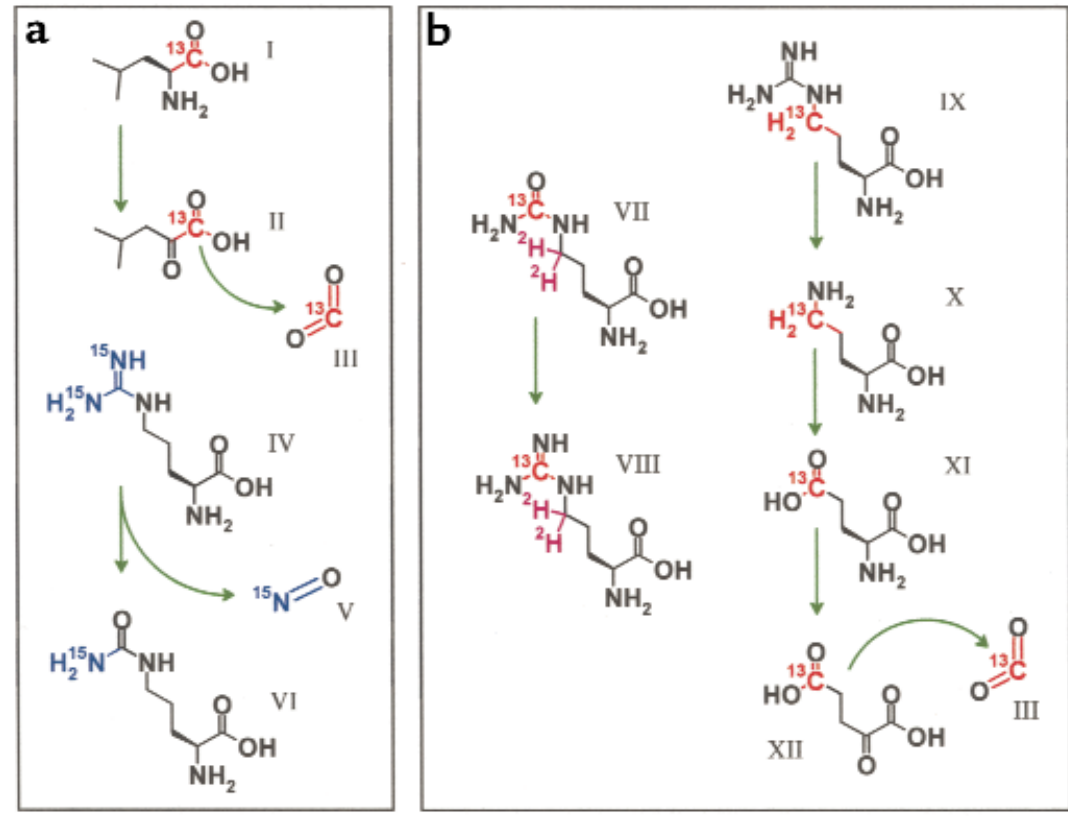

\section{Figure 3}

Illustration of the tracers used on days 1 and 3 , and their metabolic fates. (a) Day 1: [1$\left.{ }^{13} \mathrm{C}\right]$ leucine $(\mathrm{I})$ is converted to $\left[1-{ }^{13} \mathrm{C}\right] \alpha$-ketoisocaproate (II), which liberates ${ }^{13} \mathrm{CO}_{2}$ (III) during its oxidative decarboxylation. $L$ [guanidino- ${ }^{15} \mathrm{~N}_{2}$ ] arginine (IV) liberates ${ }^{15} \mathrm{NO}(\mathrm{V})$ and $\mathrm{L}-\left[{ }^{15} \mathrm{~N}\right.$-ureido $]$ citrulline $(\mathrm{VI})$ through the activity of $\mathrm{NO}$ synthase. (b) Day 3: $\mathrm{L}-\left[{ }^{13} \mathrm{C}\right]$ ureido $\left[5,5, \mathrm{H}_{2}\right]$ citrulline $(\mathrm{VII})$ is converted to $\mathrm{L}-\left[{ }^{13} \mathrm{C}\right.$-guanidino, $\left.5,5,{ }^{2} \mathrm{H}_{2}\right]$ argenine (VIII), which is used as a measure of de novo arginine synthesis. $\mathrm{L}-\left[5-{ }^{13} \mathrm{C}\right]$ arginine (IX) is converted to $\mathrm{L}-\left[5^{-13} \mathrm{C}\right]$ ornithine $(\mathrm{X})$, which is then converted to $\mathrm{L}-\left[5^{-13} \mathrm{C}\right]$ glutamic acid $(\mathrm{XI})$. The latter, via transamination, is then converted to $\left[5-{ }^{13} \mathrm{C}\right] \alpha-$ ketoglutarate (XII), which upon decarboxylation by $\alpha$-ketoglutarate dehydrogenase yields $\left[{ }^{13} \mathrm{C}\right]$ succinyl CoA (not shown). This releases its ${ }^{13} \mathrm{C}$ as ${ }^{13} \mathrm{CO}_{2}$ (III) during subsequent revolutions of the citric acid cycle.

mean daily intake of energy was $36 \pm 15 \mathrm{kcal} / \mathrm{kg}$ per day pre-hemodialysis and $35 \pm 11 \mathrm{kcal} / \mathrm{kg}$ per day post-hemodialysis.

Tracer model of amino acid kinetics. Plasma amino acid fluxes ( $\mu \mathrm{mol} / \mathrm{kg}$ per hour) were calculated from the mean of the plasma isotopic enrichment values, according to standard, steady-state isotope-dilution principles $(16,18,22)$.

The rate of citrulline conversion to arginine (net de novo arginine synthesis) (QCit $\rightarrow$ Arg, $\mu \mathrm{mol} / \mathrm{kg}$ per hour) was determined essentially according to the tracer models of Clarke and Bier (23) and Thompson (24), and as described previously (20).

The rate of arginine conversion to citrulline (NO synthesis) (QArg $\rightarrow$ Cit, $\mu \mathrm{mol} / \mathrm{kg}$ per hour) was also determined as described (18).

The rate of ${ }^{13} \mathrm{CO}_{2}$ release from ${ }^{13} \mathrm{C}$-labeled arginine $\left(\operatorname{Arg}{ }_{o x}\right)$ and rate of leucine oxidation $\left(\mathrm{Leu}_{\mathrm{ox}}\right)$, based on measurement of plasma arginine and leucine enrichments, and ${ }^{13} \mathrm{CO}_{2}$ output in expired air, was calculated as described previously (16). The ${ }^{13} \mathrm{C}$ retention factor for estimating arginine oxidation was obtained from the 2 patients receiving the $\mathrm{L}-\left[5-{ }^{13} \mathrm{C}\right]$ glutamic acid infusion (Figure 1). The results for the 2 subjects were essentially identical, with mean fractional recovery values of 0.49 and 0.43 for the pre-hemodialysis, post-absorptive, and fed periods, respectively. The comparable values were 0.45 and 0.48 , respectively, for the post-hemodialysis phase. For leucine oxidation we used values of 0.77 and 0.85 , respectively, for the postabsorptive and fed periods, as obtained previously in healthy subjects (16); these values are similar to those applied by Lim et al. (25) in studies of leucine kinetics in ESRD patients.

Evaluation of data. Arginine, leucine, and citrulline fluxes, arginine and leucine oxidation, and arginine and NO synthesis were compared separately between post-absorptive and fed states for pre-hemodialysis and post-hemodialysis patients and healthy controls using paired $t$ tests. The Kolmogorov-Smirnov goodness-of-fit test (26) was used to assess normality; no significant departures from a Gaussian distribution were detected for the variables. Within subjects, repeated measures analysis of covariance (27) was performed to compare pre- and post-hemodialysis arginine and leucine values, while adjusting for differences in arginine or leucine intake. Paired $t$ tests were used to evaluate differences in citrulline flux and NO synthesis pre- and post-hemodialysis. One-way analysis of covariance was used to assess differences in arginine and leucine fluxes and oxidation between patients with ESRD and controls, with an interaction $F$ test for checking the equality of the slopes. Unpaired $t$ tests with unequal variances were used to assess mean differences in citrulline flux and NO synthesis between ESRD patients and controls. To account for multiple comparisons, a 2-tailed, Bonferroni-adjusted $P$ value, or $P<0.017(0.05 / 3)$ was considered statistically significant for all tests. Data analysis was conducted using SAS (version 6.12; SAS Institute Inc., Cary, North Carolina, USA) and SPSS (version 7.5; SPSS Inc., Chicago, Illinois, USA) software packages. Data are expressed as mean \pm SD.

\section{Results}

Plasma isotopic abundances (net mole fraction) preand post-hemodialysis for the infused $\mathrm{L}-\left[1-{ }^{13} \mathrm{C}\right]$ leucine and L-[guanidino- ${ }^{15} \mathrm{~N}_{2}$ ] arginine are shown in Figure 4a. Values for ${ }^{\mathrm{L}}-\left[{ }^{13} \mathrm{C}\right]$ arginine and $\mathrm{L}-\left[{ }^{13} \mathrm{C}\right.$-ureido, $\left.5,5,{ }^{2} \mathrm{H}_{2}\right]$ citrulline for the pre- and post-hemodialysis studies are shown in Figure $4 \mathrm{~b}$. The pre- and posthemodialysis plasma enrichment values of $\left[{ }^{15} \mathrm{~N}\right]$ citrulline, arising from $\mathrm{L}$ guanidino- $\left.{ }^{-15} \mathrm{~N}_{2}\right]$ arginine and reflecting formation of NO, are shown in 
Table 2

Post-absorptive (PA) and fed-state plasma fluxes of L-[guanidino- $\left.{ }^{15} \mathrm{~N}_{2}\right]$ arginine, L- $\left[{ }^{13} \mathrm{C}\right.$-ureido, $\left.5,5,{ }^{2} \mathrm{H}_{2}\right]$ citrulline, and L- $\left[1-{ }^{13} \mathrm{C}\right]$ leucine and rates of arginine and NO synthesis pre- and post-hemodialysis in 6 ESRD patients and 6 healthy adults ${ }^{A}$

\begin{tabular}{|c|c|c|c|c|c|c|c|c|c|}
\hline \multirow[t]{2}{*}{ Tracer or rate } & \multicolumn{3}{|c|}{$\begin{array}{c}\text { ESRD } \\
\text { Pre-hemodialysis }\end{array}$} & \multicolumn{3}{|c|}{$\begin{array}{c}\text { ESRD } \\
\text { Post-hemodialysis }\end{array}$} & \multicolumn{3}{|c|}{$\begin{array}{c}\text { Healthy controls } \\
\text { After } 1 \text { week adequate arginine intake }\end{array}$} \\
\hline & PA & Fed & Average & PA & Fed & Average & PA & Fed & Average \\
\hline L-guanidino $\left[{ }^{15} \mathrm{~N}_{2}\right]$ arginine & $76 \pm 21$ & $77 \pm 14$ & $77 \pm 16^{\mathrm{B}}$ & $98 \pm 21$ & $94 \pm 23$ & $96 \pm 21$ & $55 \pm 10^{C}$ & $80 \pm 11$ & $68 \pm 10^{\mathrm{D}}$ \\
\hline $\mathrm{L}-\left[5-{ }^{13} \mathrm{C}\right]$ arginine & $66 \pm 16$ & $59 \pm 7$ & $62 \pm 10$ & $74 \pm 19$ & $56 \pm 9^{E}$ & $65 \pm 13$ & $53 \pm 8^{C}$ & $81 \pm 15$ & $67 \pm 11^{\mathrm{D}}$ \\
\hline L- $\left[{ }^{13} \mathrm{C}\right.$-ureido, $\left.5,5,{ }^{2} \mathrm{H}_{2}\right]$ citrulline & $67 \pm 18^{F}$ & $63 \pm 16^{\mathrm{F}}$ & $65 \pm 17^{F}$ & $87 \pm 10^{F}$ & $75 \pm 4^{F}$ & $80 \pm 6^{\mathrm{F}}$ & $18 \pm 6^{C}$ & $12 \pm 4$ & $15 \pm 5^{\mathrm{D}}$ \\
\hline L- $\left[1-{ }^{13} C\right]$ leucine & $83 \pm 13$ & $88 \pm 9$ & $87 \pm 11$ & $90 \pm 13$ & $84 \pm 18$ & $86 \pm 14$ & $78 \pm 18^{c}$ & $114 \pm 28$ & $96 \pm 21^{\mathrm{D}}$ \\
\hline Arginine synthesis & $9.6 \pm 3.0$ & $14.7 \pm 3.5$ & $12.1 \pm 2.8$ & $11.7 \pm 0.8$ & $13.7 \pm 2.1$ & $13.2 \pm 1.4$ & $6.3 \pm 1.4$ & $9.6 \pm 3.0$ & $7.9 \pm 2.1^{\mathrm{D}}$ \\
\hline NO synthesis & $4.3 \pm 2.7$ & $6.2 \pm 3.8$ & $5.2 \pm 3.1$ & $9.4 \pm 5.9^{C}$ & $8.7 \pm 4.8$ & $8.7 \pm 4.9^{G}$ & $1.0 \pm 0.2$ & $0.91 \pm 0.3$ & $0.95 \pm 0.04^{\mathrm{H}}$ \\
\hline
\end{tabular}

${ }^{A} \mathrm{All}$ values are $\mu \mathrm{mol} / \mathrm{kg}$ per hour, mean $\pm \mathrm{SD}$. ${ }^{\mathrm{B} P r e-v s}$. post-hemodialysis, $P<0.01 .{ }^{C} P<0.01$ fed vs. post-absorptive. ${ }^{\mathrm{D} F r o m}$ reference 17 . ${ }^{\mathrm{E}} P<0.05$ fed vs. postabsorptive post-hemodialysis. ${ }^{F} P<0.001$ ESRD vs. control. ${ }^{G} P<0.017$ ESRD vs. control. ${ }^{H}$ From reference 18.

Figure 5a. Enrichment of $\mathrm{L}-\left[{ }^{13} \mathrm{C}\right.$-guanidino, 5,5 , $\left.{ }^{2} \mathrm{H}_{2}\right]$ arginine formed from the $\mathrm{L}-\left[{ }^{13} \mathrm{C}\right.$-ureido, 5,5 , $\left.{ }^{2} \mathrm{H}_{2}\right]$ citrulline tracer, reflecting net de novo arginine synthesis, is presented in Figure 5b. In all cases, a steady-state isotopic enrichment plateau was achieved. The average isotopic enrichments of the L$\left[{ }^{13} \mathrm{C}\right]$ arginine tracer, pre- and post-hemodialysis, were 0.082 and 0.079 , respectively. They were higher $(P<0.05)$ than for the ${ }^{15} \mathrm{~N}_{2}$ arginine tracer $(0.070$ and 0.054 , respectively), possibly due to appearance of $\left[\right.$ mono5 $\left.-{ }^{2} \mathrm{H}\right]$ arginine $(\mathrm{M}+1)$, from the labeled citrulline after its cycling through the arginine and ornithine pools. Although our analytical procedure does not differentiate between the two $\mathrm{M}+1$ arginine species $\left({ }^{13} \mathrm{C}\right.$ - arginine or ${ }^{2} \mathrm{H}$-arginine), this would not measurably affect our kinetic values and conclusions.

Table 2 summarizes the plasma fluxes of arginine, citrulline, and leucine, and the rates of arginine and NO synthesis during the post-absorptive and fed states for the pre- and post-hemodialysis groups. Values for the healthy controls $(17,18)$ are also given in this table. As shown here, for the pre-hemodialysis phase, the amino acid fluxes did not differ between the post-absorptive and fed conditions. Similar findings apply for the posthemodialysis phase, except that the $\left[{ }^{13} \mathrm{C}\right]$ arginine flux was lower $(P<0.05)$ in the fed period than in the postabsorptive period. The general lack of change in fluxes between the post-absorptive and fed states in ESRD patients contrasts with the significant increases $(P<0.01)$ in arginine and leucine fluxes, and decrease $(P<0.01)$ in the citrulline fluxes with feeding in healthy controls. It is possible that these different responses in controls and ESRD patients for the post-absorptive and fed states are partly due to the fact that a somewhat shorter period of time elapsed between the 2 metabolic states in ESRD patients than in control subjects, or to differences in the mode of feeding (the controls were given small frequent meals) $(17,18)$, or both. Finally, the citrulline fluxes were 4-5 times higher in ESRD patients than in the healthy controls $(P<0.001)$. In comparison with our earlier estimates in healthy controls $(17,20)$, the rates of whole-body net de novo arginine synthesis appear to have been maintained in the ESRD group, despite significant renal dysfunction. The isotopically derived estimate of the rate of NO synthesis, determined from the rate of conversion of plas-

Table 3

Enrichment of ${ }^{13} \mathrm{CO}_{2}$ in expired air, carbon dioxide production $\left(V \mathrm{CO}_{2}\right),{ }^{13} \mathrm{CO}_{2}$ output $\left(V^{13} \mathrm{CO}_{2}\right)$, and oxidation and intakes of arginine and leucine after $\left[{ }^{13} \mathrm{C}\right]$ arginine and $\left[{ }^{13} \mathrm{C}\right]$ leucine infusions in ESRD patients and in healthy controls during the post-absorptive and fed states ${ }^{\mathrm{A}}$

\begin{tabular}{|c|c|c|c|c|c|c|}
\hline \multirow[b]{2}{*}{ Parameter } & \multicolumn{2}{|c|}{ Pre-hemodialysis } & \multicolumn{2}{|c|}{ Post-hemodialysis } & \multicolumn{2}{|c|}{ Healthy controls ${ }^{B}$} \\
\hline & PA & Fed & PA & Fed & PA & Fed \\
\hline \multicolumn{7}{|l|}{$\left[{ }^{13} \mathrm{C}\right]$ arginine infusion } \\
\hline $\begin{array}{l}{ }^{13} \mathrm{CO}_{2} \text { enrichment }\left(\mathrm{APE} \times 10^{-3}\right) \\
\mathrm{VCO}_{2}(\mathrm{mmol} / \mathrm{kg} \text { per hour }) \\
\mathrm{V}^{13} \mathrm{CO}_{2}(\mu \mathrm{mol} / \mathrm{kg} \text { per hour }) \\
\text { Arginine oxidation }(\mu \mathrm{mol} / \mathrm{kg} \text { per hour }) \\
\text { Dietary arginine intake }(\mu \mathrm{mol} / \mathrm{kg} \text { per hour })\end{array}$ & $\begin{array}{c}3.0 \pm 0.7 \\
7.2 \pm 1.0 \\
0.44 \pm 0.09 \\
5.5 \pm 2.0^{C} \\
0\end{array}$ & $\begin{array}{c}4.3 \pm 0.3 \\
8.9 \pm 1.3 \\
0.84 \pm 0.06 \\
7.5 \pm 1.4^{c} \\
27.0 \pm 20.0\end{array}$ & $\begin{array}{c}3.8 \pm 0.1 \\
6.6 \pm 0.02 \\
0.53 \pm 0.04 \\
5.3 \pm 2.8^{\mathrm{C}} \\
0\end{array}$ & $\begin{aligned} 4.3 & \pm 0.2 \\
5.7 & \pm 0.6 \\
0.70 & \pm 0.05 \\
8.4 & \pm 1.7 \mathrm{C} \\
31.0 & \pm 15.0\end{aligned}$ & $\begin{array}{c}18.5 \pm 5.7 \\
0\end{array}$ & $\begin{array}{l}23.6 \pm 7.9 \\
37.0 \pm 7.8\end{array}$ \\
\hline \multicolumn{7}{|l|}{$\left[{ }^{13} \mathrm{C}\right]$ leucine infusion } \\
\hline $\begin{array}{l}{ }^{13} \mathrm{CO}_{2} \text { enrichment }\left(\mathrm{APE} \times 10^{-3}\right) \\
\mathrm{VCO}_{2}(\mathrm{mmol} / \mathrm{kg} \text { per hour }) \\
V^{13} \mathrm{CO}_{2}(\mu \mathrm{mol} / \mathrm{kg} \text { per hour })\end{array}$ & $\begin{array}{l}7.09 \pm 0.10 \\
5.1 \pm 2.8 \\
0.62 \pm 0.2\end{array}$ & $\begin{array}{l}9.7 \pm 0.3 \\
7.0 \pm 1.3 \\
0.69 \pm 0.2\end{array}$ & $\begin{array}{l}7.09 \pm 0.50 \\
5.1 \pm 2.8 \\
0.74 \pm 0.3\end{array}$ & $\begin{array}{l}8.0 \pm 0.5 \\
6.7 \pm 2.0 \\
0.73 \pm 0.3\end{array}$ & & \\
\hline $\begin{array}{l}\text { Leucine oxidation ( } \mu \mathrm{mol} / \mathrm{kg} \text { per hour }) \\
\text { Dietary leucine intake }(\mu \mathrm{mol} / \mathrm{kg} \text { per hour })\end{array}$ & $\begin{array}{c}12.6 \pm 3.0^{C} \\
0\end{array}$ & $\begin{array}{l}17.0 \pm 4.0^{C} \\
43 \pm 38\end{array}$ & $\begin{array}{c}10.2 \pm 3.3^{C} \\
0\end{array}$ & $\begin{aligned} 17.3 & \pm 2.7 \mathrm{C} \\
85 & \pm 52\end{aligned}$ & $\begin{array}{c}20.5 \pm 4.5 \\
0\end{array}$ & $\begin{array}{l}37.5 \pm 14.0 \\
66.0 \pm 14.0\end{array}$ \\
\hline
\end{tabular}

AAll values are mean \pm SD. ${ }^{B}$ Taken from reference 17 and unpublished data by L. Castillo et al., 1999, for comparison. ${ }^{C P}<0.01$ ESRD vs. healthy controls. APE, atoms percent excess. 

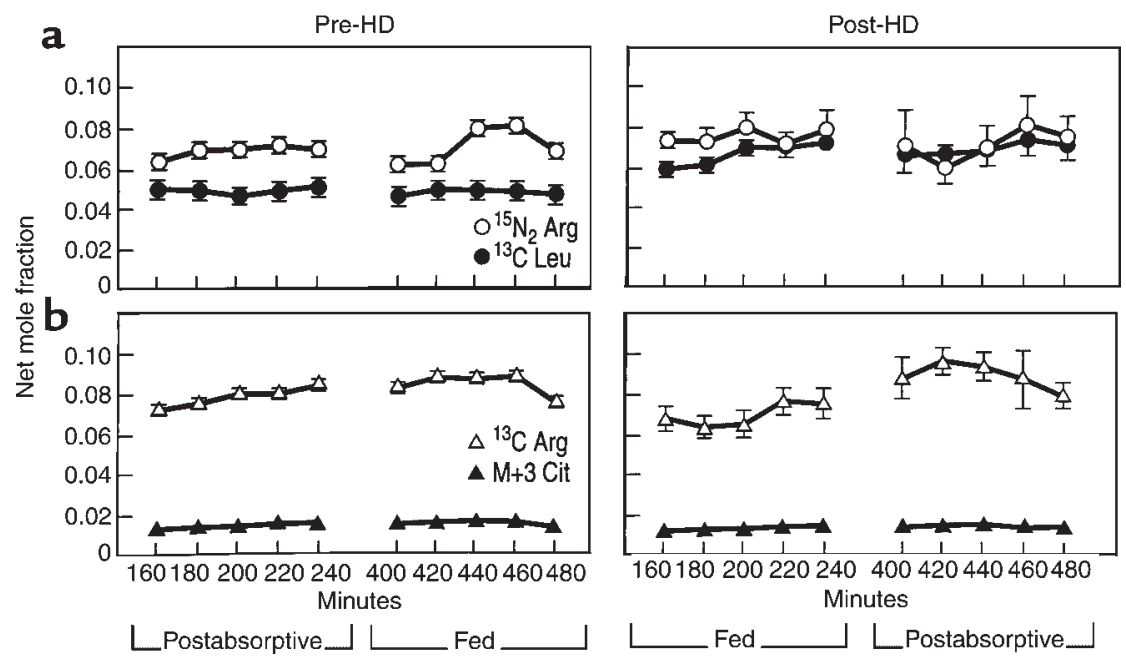

Figure 4

(a) Plasma isotopic enrichment of L-[guanidino ${ }^{15} \mathrm{~N}_{2}$ ]arginine $\left({ }^{5} \mathrm{~N}_{2} \mathrm{Arg}\right)$ and L-[1-13 C]leucine $\left({ }^{13} \mathrm{C}\right.$ Leu $)$ pre-hemodialysis (Pre-HD) and posthemodialysis(post-HD). (b) Plasma isotopic enrichment, pre- and post-hemodialysis, of L- $\left[5-{ }^{13} \mathrm{C}\right] \operatorname{arginine}\left({ }^{13} \mathrm{C} \mathrm{Arg}\right)$ and L- $\left[{ }^{13} \mathrm{C}\right.$ ureido, $\left.5,5,{ }^{2} \mathrm{H}_{2}\right]$ citrulline $(\mathrm{M}+3 \mathrm{Cit})$. Time shown is minutes of tracer infusion. Error bars are SEM.

ma $\left[{ }^{15} \mathrm{~N}_{2}\right]$ arginine to $\left[{ }^{15} \mathrm{~N}\right]$ citrulline, is also summarized in Table 2. The NO synthesis rate was $5.2 \pm 3.1 \mu \mathrm{mol} / \mathrm{kg}$ per hour $(P<0.03$ vs. healthy controls) for the prehemodialysis phase, and $8.7 \pm 4.9 \mu \mathrm{mol} / \mathrm{kg}$ per hour $(P$ $<0.017$ vs. healthy controls) for the post-hemodialysis phase; NO synthesis amounted to about $45-65 \%$ of the net rate of arginine de novo synthesis in patients with ESRD. The comparative value for healthy controls is approximately $12 \%$ (18).

Table 3 summarizes results for ${ }^{13} \mathrm{C}$ enrichment of expired air and the appearance rate of ${ }^{13} \mathrm{CO}_{2}$ in expired air in ESRD patients. Rates of $\mathrm{CO}_{2}$ production $\left(\mathrm{VCO}_{2}\right)$ ( $\mathrm{mmol} / \mathrm{kg}$ per hour) remained constant and were similar to those observed in healthy controls (16).

Arginine oxidation rates averaged $6.5 \pm 1.6 \mu \mathrm{mol} / \mathrm{kg}$ per hour and $6.9 \pm 1.1 \mu \mathrm{mol} / \mathrm{kg}$ per hour, respectively, for the entire pre- and post-hemodialysis phases; these are lower $(P<0.01)$ than those in healthy controls $(17)$. There were some differences in the estimated dietary arginine and leucine intakes between the ESRD patients and the healthy controls $(17,18)$, but these would not explain the lower rate of oxidation in patients during the post-absorptive state, or the lower leucine oxidation after hemodialysis in the fed state. Thus, it appears that rates of leucine and arginine oxidation are reduced in ESRD, due to endogenous rather than dietary factors.

Data for plasma amino acid concentrations are summarized in Table 4. There were no marked differences in arginine concentrations between the ESRD patients and healthy controls, but there were dramatic differences for citrulline, reflecting the differences in endogenous citrulline metabolism between the 2 populations. The fed-state plasma leucine concentrations were lower in ESRD patients than in controls, which is consistent with the lower fed-state rate of leucine oxidation seen in ESRD patients than in healthy subjects.

\section{Discussion}

We have investigated in vivo aspects of whole-body arginine and citrulline metabolism and rates of NO production in patients with ESRD. Our findings are evaluated in part with reference to results obtained previously in our laboratories, using comparable analytical and tracer techniques in healthy adults. We should point out, however, that there were some specific differences in experimental design between this and our earlier studies, including amounts of amino acids ingested and meal pattern, partly because it was too difficult to achieve strict dietary control with the ESRD patients who were awaiting a kidney transplant. Nevertheless, we can draw a number of new and important conclusions about the comparative aspects of arginine metabolism in ESRD patients and healthy adults.

With respect to whole-body leucine kinetics, used here as an index of the general status of body protein turnover, we did not detect profound differences between the ESRD patients and healthy controls, or evidence of a major catabolic state. The somewhat lower rates of leucine oxidation in ESRD patients during the post-absorptive phase may reflect an adaptive response to a possibly chronically lower protein intake than for our healthy subjects, as seen in our earlier long-term feeding studies of renal patients given a lowprotein diet (28). Lim et al. (29) recently reported lowered post-absorptive values of leucine oxidation in non-acidotic, chronic renal failure patients compared with controls, but protein intakes in those patients were about $75 \%$ of those in normal subjects.

Arginine homeostasis is maintained through a cooperative metabolic interaction between the intestine, liver, and kidneys. It is thought that the intestine is the net site of citrulline synthesis from which the amino acid enters the circulation (6-10) to be taken up by the 
Table 4

Plasma amino acid concentrations $(\mu \mathrm{M}$; mean \pm SD) in ESRD patients for the post-absorptive and fed states during the periods pre- and post-hemodialysis and in healthy controls

ESRD

Amino acid

Arginine

Citrulline

Leucine

\begin{tabular}{|c|c|}
\hline \multicolumn{2}{|c|}{ Pre-hemodialysis } \\
\hline $\mathrm{PA}^{\mathrm{B}}$ & $\mathrm{Fed}^{\mathrm{C}}$ \\
\hline 32 & $100 \pm 29$ \\
\hline $63 \pm 13^{\mathrm{H}}$ & $68 \pm 20^{\mathrm{H}}$ \\
\hline $27 \pm 16$ & $108 \pm 38$ \\
\hline
\end{tabular}

Healthy controls ${ }^{\mathrm{A}}$

\begin{tabular}{cccc}
\multicolumn{4}{c}{ Post-hemodialysis } \\
PA $^{\mathrm{D}}$ & Fed $^{\mathrm{E}}$ & $\mathrm{PA}^{\mathrm{F}}$ & Fed $^{\mathrm{G}}$ \\
$104 \pm 14$ & $84 \pm 25$ & $96 \pm 25$ & $124 \pm 14$ \\
$74 \pm 19^{\mathrm{H}}$ & $51 \pm 10^{\mathrm{H}}$ & $25 \pm 2$ & $18 \pm 1$ \\
$119 \pm 24$ & $93 \pm 25^{\mathrm{I}}$ & $145 \pm 8$ & $190 \pm 20$
\end{tabular}

ADerived from study described in reference 17 and unpublished data of L. Castillo et al., 1999. B,CMeasurement taken at 0 minutes and mean times of 460 and 480 minutes, respectively (see Figure 2a). D,E Measurement taken at mean of 460 and 480 minutes, and 220 and 240 minutes, respectively (see Figure 2 b). F,GMean values for 12 -hour post-absorptive and 12 -hour fed periods of the 24 -hour tracer study, respectively. ${ }^{H P}<0.01$ ESRD vs. healthy controls. $P<0.01$ ESRD vs. healthy controls.

kidneys. Here the conversion of citrulline to arginine (de novo arginine synthesis) takes place, almost exclusively in the proximal convoluted tubule, through the action of the cytosolic enzymes argininosuccinate synthetase (EC 6.3.4.5) and argininosuccinate lyase (EC 4.3.2.1) (6-8). The kidneys, therefore, have been considered to be the main organ site for net de novo arginine synthesis in the maintenance of the whole-body arginine economy. This view is supported by the findings of Tizianello et al. (30), who measured arteriovenous renal gradients of amino acids in healthy humans and in patients with chronic renal failure. They showed that in the latter individuals, a net citrulline uptake was balanced by an equal net arginine output, which overall was $40 \%$ less than in healthy subjects.

Our study has revealed maintenance in the net rate of de novo arginine synthesis in patients with ESRD, notwithstanding that renal function was severely compromised, as demonstrated by a creatinine clearance of less than $10 \%$ of a normal value. The mechanism (or mechanisms) responsible for this maintenance of arginine synthesis remains to be established. Dhanakoti and coworkers (31) demonstrated in rats that renal arginine production is independent of dietary arginine, but that availability of citrulline was the limiting factor for renal arginine synthesis. Also, studies in a rat model of chronic renal failure, induced by $5 / 6$ nephrectomy (32), showed that arginine synthesis was maintained. Three possible causes given for this were hypertrophy of the proximal tubule in remnant nephrons, which might double the arginine synthesis capacity per nephron; hyperfiltration, which increases the amount of citrulline filtered per nephron; and increased plasma citrulline concentrations. In our ESRD patients, the plasma rate of appearance of citrulline flux was significantly elevated, together with a markedly higher than normal plasma citrulline concentration. The latter has been reported by other researchers (30) in patients with ESRD, together with an observed inverse correlation between the plasma
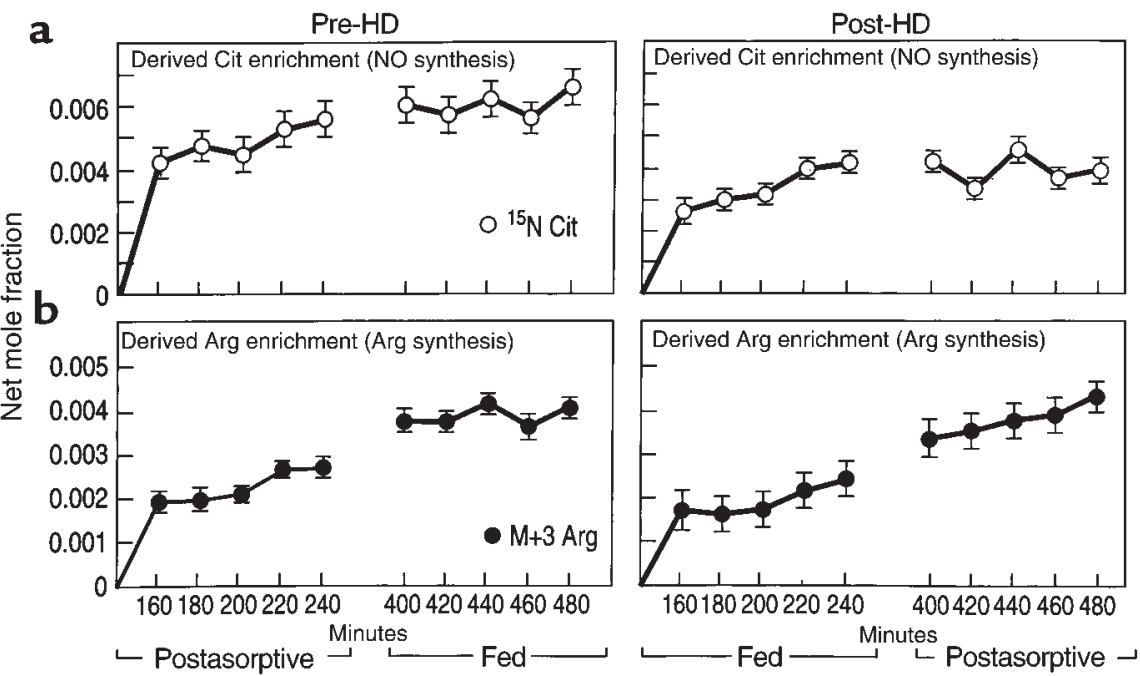

Figure 5

(a) Plasma isotopic enrichment of [ ${ }^{15} \mathrm{~N}$-ureido]citrulline ( ${ }^{15} \mathrm{~N}$ Cit; $\mathrm{Vl}$ in Figure 3 ) derived from L-[guanidino-- $\left.{ }^{15} \mathrm{~N}_{2}\right]$ arginine (IV in Figure 3 ), an index of $\mathrm{NO}$ synthesis, pre- and post-hemodialysis. (b) Plasma isotopic enrichment of $\mathrm{L}-\left[{ }^{13} \mathrm{C}\right.$-guanidino, $5,5,{ }^{13} \mathrm{C}$-guanidino, $\left.5,5,{ }^{2} \mathrm{H}_{2}\right]$ arginine $\left(\mathrm{M}+3 \mathrm{Arg}\right.$; VIII in Figure 3) derived from L-[ ${ }^{13} \mathrm{C}$-ureido5,5, $\left.{ }^{2} \mathrm{H}_{2}\right]$ citrulline (VII in Figure 3), an index of arginine synthesis, pre- and post-hemodialysis. Time shown is minutes of tracer infusion. Error bars are SEM. 
citrulline concentrations and renal function (30). According to the findings of Bouby and coworkers (32), the higher citrulline turnover may be a peripheral adaptation, enabling a reduced mass of functional tissue in the kidney to maintain a constant rate of arginine synthesis.

The rate of citrulline appearance (and disappearance) was about $65-80 \mu \mathrm{mol} / \mathrm{kg}$ per hour in the ESRD patients. This is about 4 or 5 times higher than in healthy controls (20). It also exceeds the net rate of de novo arginine synthesis, which approximates 13 $\mu \mathrm{mol} / \mathrm{kg}$ per hour. Because the only route of citrulline catabolism is arginine synthesis, this must indicate a significant compartmentation of citrulline metabolism in vivo. Clearly, further detailed studies of citrulline metabolism in ESRD would be worthwhile, possibly using compartmental modeling (33).

We observed that the rate of arginine oxidation during the post-absorptive state in patients with ESRD was about $30 \%$ of that for healthy controls. In healthy subjects we have shown an adaptive reduction in arginine oxidation when they were fed an arginine-free diet $(17,22)$, which is associated with a lowered plasma arginine concentration (17, 22; unpublished data). In contrast, the lowered rate of arginine oxidation in the ESRD patients was associated with a normal plasma arginine concentration. This implies a diet-independent change in arginine metabolism in patients with severe renal dysfunction.

It can be seen from Table 3 that the rate of intake of arginine exceeded the estimated rate of arginine oxidation over the combined post-absorptive and fed states. On this basis, the patients were in marked positive arginine balance during the tracer study. Because a positive arginine balance would not be sustained over a prolonged period, the possibility exists that we have underestimated the rate of arginine oxidation. However, because this limitation would probably also apply to oxidation values for healthy controls, it seems that there are differences between the patient and control groups. Similarly, leucine oxidation for the combined post-absorptive and fed states indicated a positive leucine balance that tended to be greater during the post-hemodialysis phase. In comparison, the healthy subjects were close to leucine balance, again suggesting a retention of body protein in ESRD patients during the period of the tracer studies.

Finally, we have observed increased rates of NO synthesis in ESRD patients, although acute hemodialysis treatment did not appear to change the rate of NO production. Yokokawa and coworkers (34) demonstrated increased production of NO, determined by plasma nitrite and nitrate concentrations, in patients with ESRD and hemodialysis-induced hypotensive episodes. However, NO production evaluated in this way did not appear to increase in their ESRD patients who were undergoing hemodialysis but were without hypotensive episodes. In contrast, our ESRD patients receiving hemodialysis treatment remained hemody- namically stable, but presented a significant increase in NO production. Wever et al. (35), using L-[guanidino- ${ }^{15} \mathrm{~N}_{2}$ ] arginine in a tracer paradigm comparable to the one used here for determination of NO production, reported a reduced rate of NO production in patients with chronic renal failure who were not on hemodialysis. Thus, the consequences for NO production of ESRD appear to be complex, and this will require additional study.

In summary, our findings indicate that arginine homeostasis under conditions of ESRD is supported by maintenance in the rate of net de novo arginine synthesis, apparently due to an adaptive increase in the rate of citrulline synthesis and maintenance of high plasma levels and turnover. The anatomic site or sites responsible for net arginine synthesis under these conditions remain to be established. Arginine may also be conserved in part by a lower post-absorptive rate of oxidation. In addition, the rate of NO synthesis in patients with ESRD was significantly elevated, and accounted for a much higher fraction of arginine disposal than in healthy subjects. In comparison with healthy subjects, the altered dynamic relationships in ESRD among arginine and citrulline metabolism on the one hand, and NO synthesis on the other, indicate the need to further investigate the pathophysiological implications of arginine and citrulline metabolism in patients with severe renal disease.

\section{Acknowledgments}

This study was supported by funding from the Anesthesia Research Foundation, by the Children's Hospital, the Lynne Reid Fellowship at Harvard Medical School, and by National Institutes of Health grants RR88, DK-15856, DK-40561, and P30-DK40561.

1. Barbul, A. 1986. Arginine: biochemistry, physiology and therapeutic implications. JPEN J. Parenter. Enteral Nutr. 10:227-238.

2. Nathan, C. 1992. Nitric oxide as a secretory product of mammalian cells. FASEB J. 6:3051-3056.

3. Schwartz, D, et al. 1997. Agmatine affects glomerular filtration via a nitric oxide synthase-dependent mechanism. Am. J. Physiol. 272:F597-F601.

4. Morgan, D. 1994. Polyamines, arginine and nitric oxide. Biochem. Soc. Trans. 22:879-883.

5. Dhanakoti, S.N., Brosnan, M.E., Herzberg, G.R., and Brosnan, J.T. 1992. Cellular and subcellular localization of enzymes of arginine metabolism in rat kidney. Biochem. J. 282:369-375.

6. Featherston, W.R., Rogers, Q.R., and Freedland, R.A. 1973. Relative importance of kidney and liver in synthesis of arginine by the rat. Am.J. Physiol. 224:127-129.

7. Dhanakoti, S.N., Brosnan, J.T., Herzberg, G.R., and Brosnan, M.E. 1990. Renal arginine synthesis: studies in vitro and in vivo. Am. J. Physiol. 259:E437-E442.

8. Levillain, O., Hus-Citharel, A., Morel, F., and Bankir, L. 1990. Localization of arginine synthesis along rat nephron. Am. J. Physiol. 259:F916-F923.

9. Levillain, O., Hus-Citharel, A., Morel, A., and Bankir, L. 1993. Arginine synthesis in mouse and rabbit nephron: localization and functional significance. Am. J. Physiol. 264:F1038-F1045.

10. Wu, G., and Morris, S.M., Jr. 1998. Arginine metabolism: nitric oxide and beyond. Biochem. J. 336:1-17.

11. Reyes, A.A., Karl, I.E., and Klahr, S. 1994. Role of arginine in health and in renal disease. Am. J. Physiol. 267:F331-F346.

12. Beasley, D., and Brenner, B.M. 1992. Role of nitric oxide in hemodialysis hypotension. Kidney Int. 42:S96-S100.

13. Vallance, P., Leone, A., Calver, A., Collier, J., and Moncada, S. 1992. Accumulation of an endogenous inhibitor of nitric oxide synthesis in chronic renal failure. Lancet. 339:572-575.

14. Wolfson, M., Jones, M.R., and Kopple, J.D. 1982. Amino acid losses dur- 
ing hemodialysis with infusion of amino acids and glucose. Kidney Int 21:500-506.

15. Blumenkrantz, M.J., et al. 1981. Protein losses during peritoneal dialysis. Kidney Int. 19:593-602.

16. El-Khoury, A.E., et al. 1994. Validation of the tracer balance concept with reference to leucine: 24 -h intravenous tracer studies with $\mathrm{L}-\left[1-{ }^{13} \mathrm{C}\right]$ leucine and $\left[{ }^{15} \mathrm{~N}-{ }^{15} \mathrm{~N}\right]$ urea. Am. J. Clin. Nutr. 59:1000-1011.

17. Castillo, L., Bedri, S., Beaumier, L., Ajami, A.M., and Young, V.R. 1997. Adaptation to a long term (4 weeks) arginine precursor-free diet in adult humans. FASEB J. 11:439a. (Abstr.)

18. Castillo, L., Beaumier, L., Ajami, A.M., and Young, V.R. 1996. Whole body nitric oxide synthesis in healthy men determined from $\left[{ }^{15} \mathrm{~N}\right]$ arginine-to$\left[{ }^{15} \mathrm{~N}\right]$ citrulline labeling. Proc. Natl. Acad. Sci. USA. 93:11460-11465.

19. Castillo, L., et al. 1994. Plasma arginine kinetics in adult man: response to an arginine-free diet. Metabolism. 43:114-120.

20. Castillo, L., et al. 1993. Plasma arginine and citrulline kinetics in adults given adequate and arginine-free diets. Proc. Natl. Acad. Sci. USA. 90:7749-7753.

21. Castillo, L., et al. 1993. Splanchnic metabolism of dietary arginine in relation to nitric oxide synthesis in normal man. Proc. Natl. Acad. Sci. USA. 90:193-197.

22. Castillo, L., et al. 1994. The plasma flux and oxidation rate of ornithine adaptively decline with restricted arginine intake. Proc. Natl. Acad. Sci. USA. 91:6393-6397.

23. Clarke, J.T., and Bier, D.M. 1982. The conversion of phenylalanine to tyrosine in man. Direct measurement by continuous intravenous tracer infusions of L-[ring- $\left.{ }^{2} \mathrm{H}_{5}\right]$ phenylalanine and $\mathrm{L}-\left[1-{ }^{13} \mathrm{C}\right]$ tyrosine in the postabsorptive state. Metabolism. 31:999-1005.

24. Thompson, G.N., et al. 1989. Rapid measurement of whole body and forearm protein turnover using a $\left[{ }^{2} \mathrm{H}_{5}\right]$ phenylalanine model. Am. J. Phys- iol. 256:E473-E479.

25. Lim, V.S., Bier, D.M., Flanigan, M.J., and Sum-Ping, S.T. 1993. The effect of hemodialysis on protein metabolism. A leucine kinetic study. J. Clin. Invest. 91:2429-2436.

26. Zar, J.H.1966. Biostatistical analysis. 3rd edition. Prentice Hall. Upper Saddle River, NJ. 474-480.

27. Littell, R., Freund, R., and Spector, P. 1991. SAS systems for linear models. 3rd edition. SAS Institute Inc. Cary, NC. 229-246.

28. Tom, K., et al. 1995. Long-term adaptive responses to dietary protein restriction in chronic renal failure. Am. J. Physiol. 268:E668-E677.

29. Lim, V.S., Yarasheski, K.E., and Flanigan, M.J. 1998. The effect of uraemia, acidosis, and dialysis treatment on protein metabolism: a longitudinal leucine kinetic study. Nephrol. Dial. Transplant. 13:1723-1730.

30. Tizianello, A., De Ferrari, G., Garibotto, G., Gurrei, G., and Robaudo, C. 1980. Renal metabolism of amino acids and ammonia in subjects with normal renal function and in patients with chronic renal insufficiency. J. Clin. Invest. 65:1162-1173.

31. Dhanakoti, S.N., Brosnan, J.T., Brosnan, M.E., and Herzberg, G.R. 1992. Net renal arginine flux in rats is not affected by dietary arginine or dietary protein intake. J. Nutr. 122:1127-1134.

32. Bouby, N., Hassler, C., Parvy, P., and Bankir, L. 1993. Renal synthesis of arginine in chronic renal failure: In vivo and in vitro studies in rats with 5/6 nephrectomy. Kidney Int. 44:676-683.

33. Cobelli, C., and Caumo, A. 1998. Using what is accessible to measure that which is not: necessity of model of system. Metabolism. 47:1009-1035.

34. Yokokawa, K., et al. 1995. Increased nitric oxide production in patients with hypotension during hemodialysis. Ann. Intern. Med. 123:35-37.

35. Wever, R., et al. 1999. Nitric oxide production is reduced in patients with chronic renal failure. Arterioscler. Thromb. Vasc. Biol. 19:1168-1172. 